\title{
New insights into Troglotella incrustans WERNLI \& FOOKES, 1992, a fascinating Upper Jurassic-Upper Cretaceous foraminifer
}

\author{
Felix SCHLAGINTWEIT \\ Lerchenauerstr. 167, 80935 München, Germany
}

Received February 2012; accepted April 2012

Available online 25 May 2012

DOI: $10.5038 / 1937-8602.57 .2 .2$

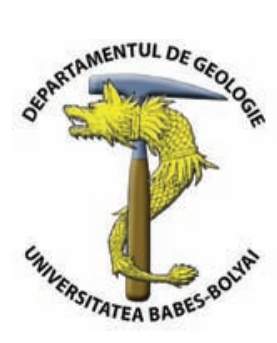

\begin{abstract}
New data about the highly variable test morphology of the benthic foraminifer Troglotella incrustans WERNLI \& FOOKES (Oxfordian-Lower Cenomanian) are presented, permitting an emended species/genus diagnosis. This concerns mainly the existence of a large final chamber with fistulose extensions that may follow the uniserial or the irregular-branching test part. The way of life of $T$. incrustans (cryptoendolithic vs. euendolithic) is discussed against the background of different existing models in the literature. The study is based on material (thin-sections and provided photographs) mainly from the Upper Jurassic of Austria, Italy, Romania, Ukraine, and also the type-locality of France.
\end{abstract}

Key words: Bioerosion, Lithocodium, Troglotella, foraminifera, boring sponges, Entobia, microbialites.

\section{INTRODUCTION}

The Upper Jurassic typical association of the foraminifer Troglotella incrustans WERNLI \& FOOKES, 1992 (type-stratum /locality: Upper Jurassic of France) with the enigmatic crustforming microfossil Lithocodium aggregatum ELLIOTT, 1956 (type-stratum/locality: Lower Cretaceous of Iraq) was described in details by Schmid and Leinfelder (1996) and interpreted as a consortium of two foraminifera. In this interpretation, Troglotella was dwelling cryptobiotically inside the large empty sparite-filled chambers (or "basal cavities") of Lithocodium. The dark micritic tissue with its system of branching alveoles was interpreted as representing the pseudo-alveolar wall of the loftusiacean foraminifer Lithocodium aggregatum ELLIOTT. A completely different interpretation was presented recently by Schlagintweit (2010), referring the large cavities/chambers with their canal system to the traces of boring sponges (ichnogenus Entobia) excavating their galleries into microbial crusts, a view expressed also by Cherchi and Schroeder (2010) for Upper Triassic forms of "Lithocodium" (see also Schlagintweit, 2011). Smaller cavities that closely follow the test morphology of the foraminifer (different from the large "basal cavities") and also illustrated by Schmid and Leinfelder (1996) maybe produced by Troglotella itself.

This paper presents new thin-section data about these highly disputed taxa including interpretation, morphological variability, and comparisons. The data are presented and discussed in two different chapters. Based on a nice specimen from the Upper Jurassic of Romania, the interpretation of the "LithocodiumTroglotella consortium" is exemplified in the first part of the paper. In the second part, remarks on the morphologically highly variable foraminifer Troglotella incrustans WERNLI \& FOOKES are given, including also a genus/species emendation. *Correspondence: F. Schlagintweit (ef.schlagintweit@t-online.de)
Together with new observations, the way of life of Troglotella incrustans is discussed against the background of previous assumptions.

\section{PALEONTOLOGICAL PART}

\section{1. "Lithocodium"-Troglotella consortium}

Material: The sample comes from the Bicaz Valley of the Hăghimaş Mountains, Eastern Carpathians, Romania. It was illustrated by Bucur and Săsăran (2011) on Pl. 4, Fig. 14 as "Lithocodium aggregatum ELLIOTT; crust on a bivalve shell, sample 11484". It is here re-illustrated in Fig. 1. Stratigraphy is indicated as Upper Tithonian.

Description: A bivalve shell within a predominantly micritic matrix shows a micritic crust (thickness up to $1 \mathrm{~mm}$ ) with one specimen of the "Lithocodium-Troglotella consortium" sensu Schmid and Leinfelder (1996) (Fig. 1a). It consists of a compressed-ovoidal, sparite-filled "basal cavity" with a convex base that contains a specimen of Troglotella incrustans WERNLI $\&$ FOOKES with three uniserial arranged ovoid to elongated chambers preserved. The height of the biconvex, lens-shaped "basal cavity" is about 2.5 times the maximum chamber width of Troglotella. From the roof of the "basal cavity", bifurcating canals (diameter $0.01-0.11 \mathrm{~mm}$ ) are radiating laterally limited by the two elongated ends of the cavity. The bivalve shell interior is sparitic and contains some bioclasts bridged by thin micritic laminae.

Interpretation: The shown example fits with the concept of Schmid and Leinfelder (1996) that Troglotella incrustans is dwelling in large, sparite-filled cavities. According to Schmid and Leinfelder (1996), these hollow structures should represent the basal cavities of Lithocodium aggregatum. The base of the "basal cavity" cuts obliquely an encrusting (or boring?) foraminifer 
with a hyaline-calcitic wall (or cement layer at the inner side of a thin microcrystalline wall?) and with its lowermost part excavates parts of the bivalve shell (Fig. 1b). This clearly bioerosive feature, however, is incompatible with the concept of Schmid and Leinfelder (1996). It should be mentioned that in their emended diagnosis of "Lithocodium aggregatum" (based on Upper Jurassic material of Portugal), Schmid and Leinfelder (1996, p. 24) remarked that the substrat serving as "attachment surface"...."maybe etched". However, neither a bioeroding way of life of "Lithocodium aggregatum" nor the origin/producer of these etching traces were further discussed and substantiated. The bifurcating canals arising from the top of the "basal cavity" radiate laterally into the micritic crust. These canals are lacking in other parts of the micritic crust, visible on the right side above the partly bioeroded hyaline foraminifer. This observation documents that the same organism that also created the spar-filled cavity produced the canals. In this example, it is obvious that Troglotella was not the producer itself as it shows a morphology completely different from the chamber/cavity and also the size is differing considerably. Thus, Troglotella occurs nestling in the taphonomic refugium of the cavities. It is worth mentioning, that in the Upper Jurassic material the sparite-filled single chambers may be also empty, without Troglotella inside (Fig. 2a). Therefore it can be assumed that Troglotella was only nestling inside the cavity presumably after the death and decay of its producer. The last elongated chamber of Troglotella stretches into the canal delimiting the cavity on the left side.

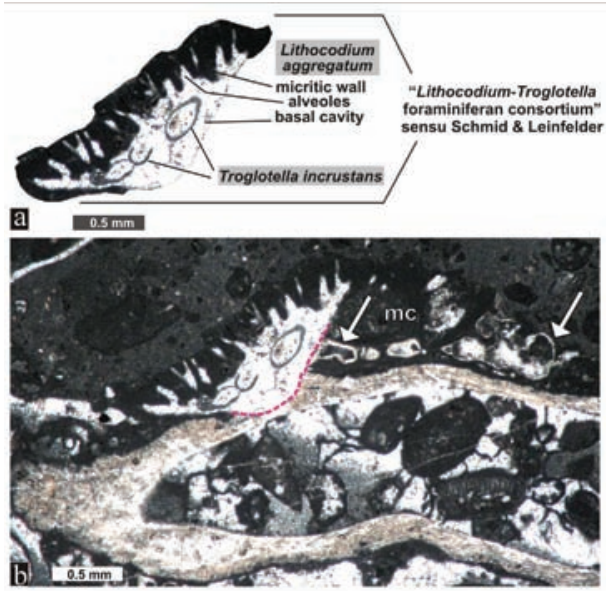

Fig. 1. a: "Lithocodium"-Troglotella foraminiferan consortium sensu Schmid and Leinfelder (1996) from the Upper Jurassic of the Eastern Carpathians of Romania, detail cut out from (b) (see Bucur and Săsăran, 2011, Pl. 4, Fig. 14). b: The greater view of (a) shows that the Lithocodium-Troglotella consortium represents a bioerosive structure cutting obliquely a uniserial hyaline calcite encrusting (or boring?) foraminifer (on the right). The lowermost part of the chamber/cavity excavates into the bivalve shell. The lack of the bifurcating canals laterally of the chamber-canal boring system documents that the micritic mass is not part of this structure but represents some kind of microbial crust enveloping a bivalve shell.

Taking into account the bioerosive character of the structure (cavity + radiating canals), however, it is different from the Lower Cretaceous Lithocodium aggregatum ELLIOTT that is interpreted as a filamentous crust-forming organism, either of chlorophycean (Schlagintweit et al., 2010; Schlagintweit and Bover-Arnal, 2012) or cyanobacterian nature (Cherchi and Schroeder, 2006, 2010). Instead, these boring galleries can be enclosed in the morphological variability of the ichnogenus Entobia BRONN, 1838 (Cherchi and Schroeder, 2010; Schlagintweit, 2010, 2011). In fact, the uni-camerate Upper Jurassic form with its canal system Studia UBB Geologia, 2012, 57 (2), 17 - 26 can generally be compared to the Palaeozoic Entobia devonica (Tapanila, 2006), the Upper Cretaceous Entobia cracovensis (Bromley et al., 2009) (see Schlagintweit, 2010) or the Miocene Entobia resinensis (Santos et al., 2011) (Fig. 2b-g). These borings were directly compared with modern clionid sponges as modern trace-making analogues (e.g., Schönberg and Tapanila, 2006). The diameter of the chambers is 0.15 to $2.64 \mathrm{~mm}$ for the Upper Triassic (Cherchi and Schroeder, 2010; Schlagintweit, 2011) and 0.5 to 4.6 $\mathrm{mm}$ for the Upper Jurassic forms (see Fig. 2a, specimen on the right). The Miocene Entobia resinensis has distinctly larger chambers with a diameter from $3.3 \mathrm{~mm}$ to $57.6 \mathrm{~mm}$ (Santos et al., 2011).
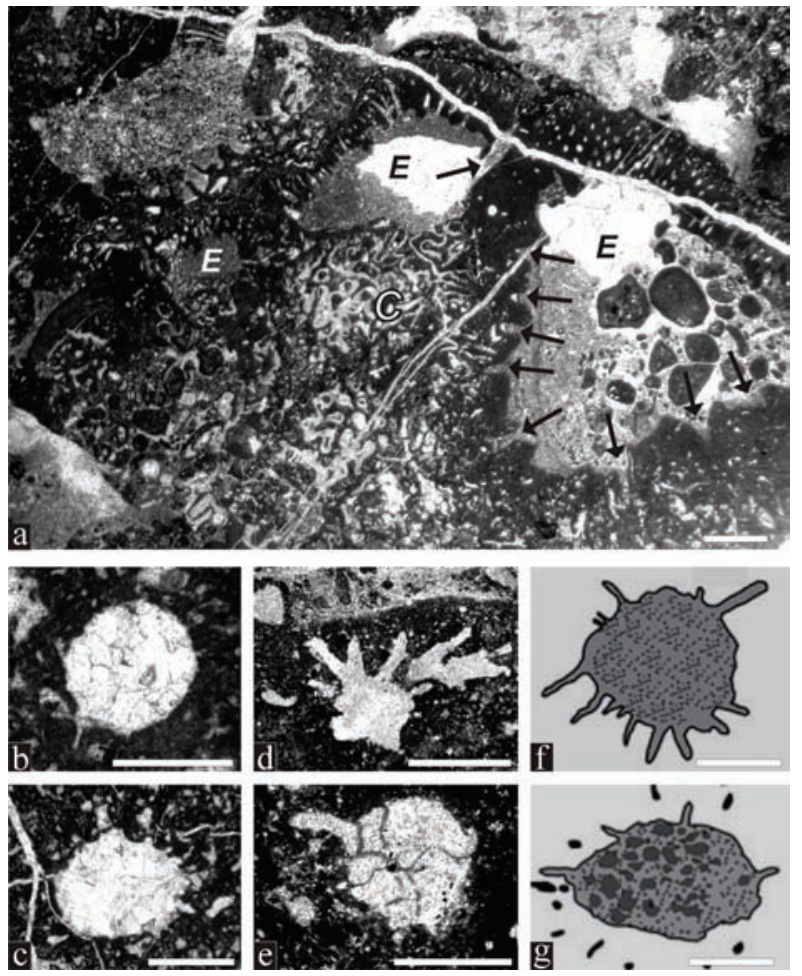

Fig. 2. Transverse to slightly oblique sections of Upper Triassic (bc) and Upper Jurassic (a, d-e) entobians (scale bars $0.5 \mathrm{~mm}$ ) of the Northern Calcareous Alps (Austria) boring into calcimicrobial crusts compared with other unicamerate forms, e.g., Entobia resinensis SANTOS, MAYORAL \& BROMLEY $(\boldsymbol{f}-\boldsymbol{g})$ from the Miocene of Spain (part from Fig. 3 of Santos et al., 2011, modified, without scale). Note the canals radiating from the chamber (arrows) in a; $C=$ encrusting foraminifer Coscinophragma aff. cribrosa (REUSS). Note the lack of Troglotella incrustans WERNLI \& FOOKES in both the crusts and the empty sponge chambers exhibiting geopetal fillings. a: Mount Hoher Rosenkogel, thin-section GW 33. b-c: Mount Steinplatte. d-e: Mount Dietrichshorn. Scale bars $=1 \mathrm{~mm}$, except $f-g$ without scale.

In some of the chambers of the Late Jurassic material, more or less equivalent sized bodies (but smaller than the chamber) showing a thin body wall were observed and interpreted as preserved remnants of the bioeroding sponges also with morphological analogy to modern taxa (Schlagintweit, 2010, 2011)

The micritic ,tissue“ referred to the "foraminiferan wall“ of „Lithocodium“ by Schmid and Leinfelder (1996) in fact is interpreted as representing calcimicrobial crusts that envelope bioclastic substrates. These crusts may be girvanellid, porostromate or „bacinellid“ (Fig. 3) or dense micritic as certain types of oncoid cortices as evidenced from Upper Jurassic material of Austria (Schlagintweit, 2010). In „bacinellid“ crusts the chambers of Troglotella are sometimes difficult to discern 
and hidden within the vesicular meshwork both sparfilled and both with thin micritic walls (Figs. 3c, d).
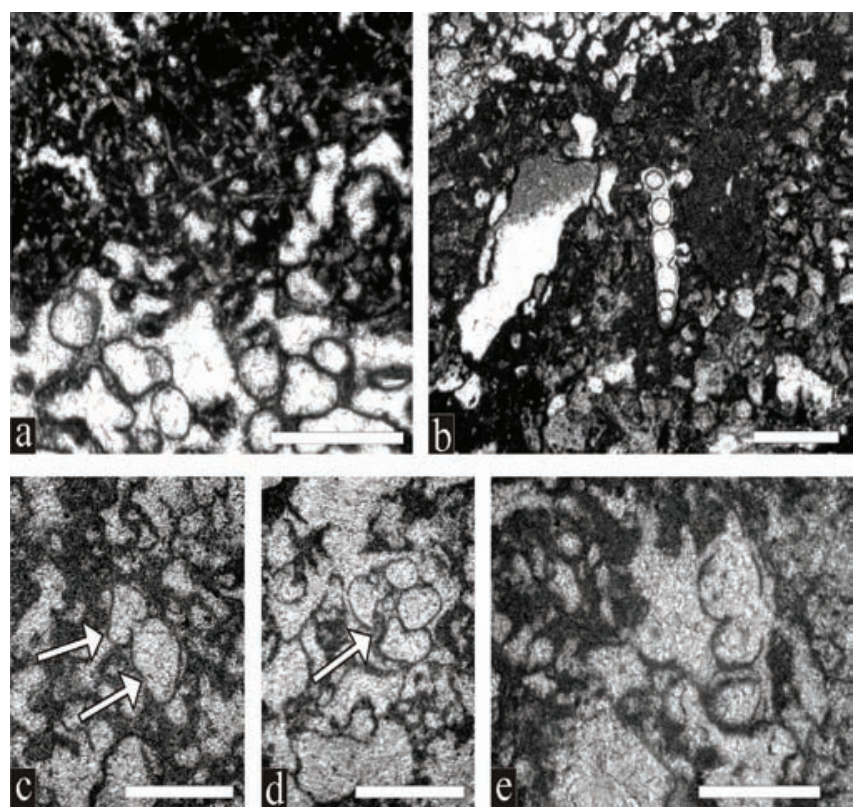

Fig. 3. Troglotella incrustans WERNLI \& FOOKES from the Upper Jurassic of the Northern Calcareous Alps of Austria. (a), Crimea Mountains, S-Ukraine (b) (material M. Krajewski), and Upper Jurassic or Neocomian of Eastern Serbia (material R. Radoičić) (c-e). a: Irregular adult test part within porostromate crust, Mount Trisselwand, thin-section T 136. b: Juvenile specimen exhibiting six uniserial chambers within "bacinellid" crust. Thin-section KE $4 b$. c-e: Specimens of Troglotella incrustans hidden within "bacinellid" crusts. For clear identification within the spar-filled meshwork, chambers of Troglotella are marked with arrows. Thin-section RR 3367. Scale bars $0.5 \mathrm{~mm}$.

\section{Troglotella incrustans WERNLI \& FOOKES}

Material: The illustrated thin-section specimens are from the Upper Jurassic of the Northern Calcareous Alps of Austria (see Gawlick et al., 2009; Schlagintweit, 2010), the Hăghimaş Mountains (see Bucur and Săsăran, 2011) and the Trascău Mountians (see Săsăran, 2006) of the Eastern Carpathians, Romania, the Madonie Mountains of Sicily, Italy (see Bucur et al., 1996) and the Crimea Mountains of S-Ukraine (see Krajewski, 2010). Furthermore, the study is supplemented by illustrations of specimens from Wernli and Fookes (1992) and unpublished material from the Kimmeridgian type-locality St. Germain-de-Joux (southeastern France). Remarks (including discussion) are given about the test morphology, the way of life and the biostratigraphy of Troglotella incrustans. An emended diagnosis for the genus is also presented. The suprageneric attribution of Troglotella within the foraminifera is adopted from Schmid and Leinfelder (1996).

Superfamily Hormosinacea Haeckel

Family Telamminidae Loeblich \& Tappan

Genus Troglotella WERNLI \& FOOKES, 1992

Troglotella incrustans WERNLI \& FOOKES (Fig. 1a, b pars, Fig. 3-10)

Selected synonymy:

1991 Boring foraminifer gen. et sp. indet. - Schlagintweit, p. 44, Pl. 10, Figs. 13-14.

1992 Troglotella incrustans nov. gen., nov. sp. - Wernli \& Fookes, p. 97, P1. 1-2.

1996 Troglotella incrustans WERNLI \& FOOKES - Bucur et al., p. 69, Pl. 2, Fig. 3, Pl. 5, Figs. 6, 9-10.
1996 Troglotella incrustans WERNLI \& FOOKES - Schmid \& Leinfelder, p. 25, Pl. 1, Figs. 1-4, Pl. 2, Figs. 1-6, Text-Figs. 1-8 (with synonymy).

1997 Troglotella incrustans WERNLI \& FOOKES Kolodziej, Figs. 2a-f (pars); Fig. 3.

2005 Troglotella incrustans WERNLI \& FOOKES Schlagintweit et al., p. 46, Fig. 29 a-c (with synonymy).

2010 Troglotella incrustans WERNLI \& FOOKES Krajewski, Fig. 4.33/C (pars), Fig. 4.35/A (pars), Fig. 4.39/D (pars), Fig. 4.41/D (pars), Fig. 4.52/C (pars), Fig. 4.57/D (pars), Fig. 4.67/A (pars).

2011 Troglotella incrustans WERNLI \& FOOKES - Bucur \& Săsăran, Pl. 2, Fig. 5, Pl. 4, Figs. 12, 14 (pars), Pl. 5, Figs. 4-6, Pl. 16, Fig. 3 (pars).

Test morphology: The test morphology of Troglotella is highly variable e.g., Figs. 4-7).
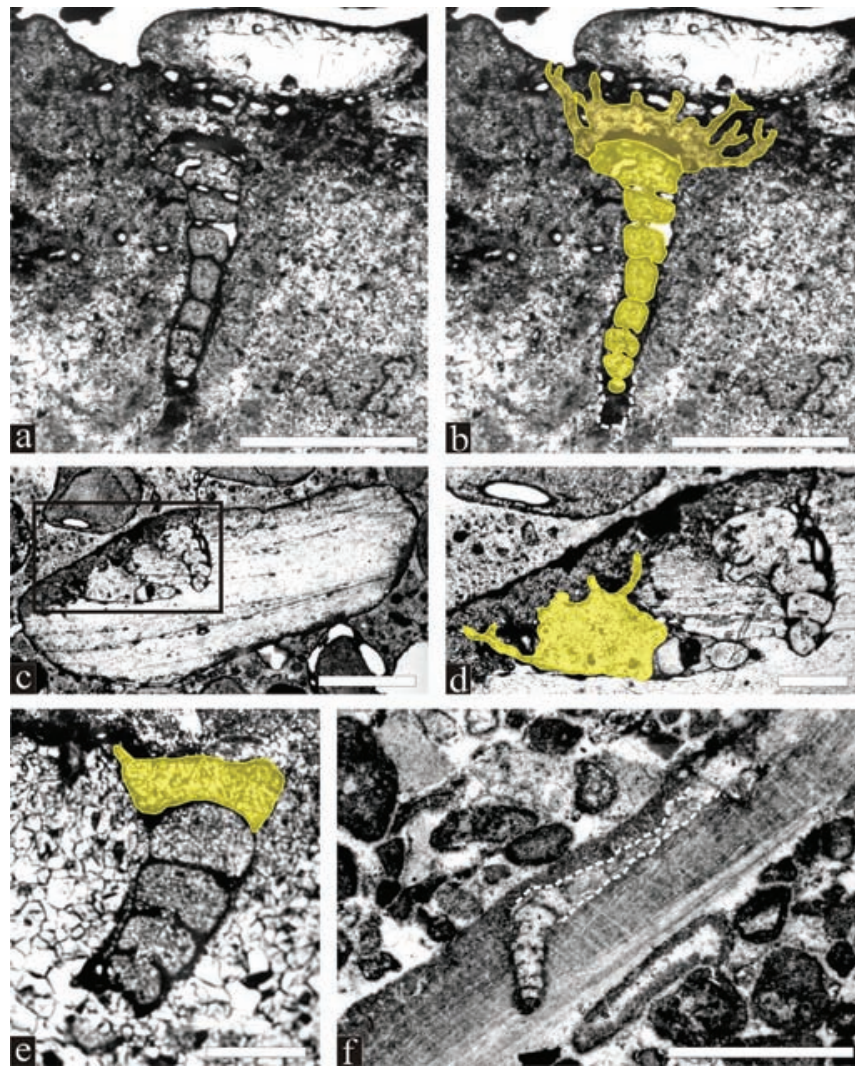

Fig. 4. Troglotella incrustans WERNLI \& FOOKES from the typelocality, the Kimmeridgian of St. Germain-de-Joux, southeastern France. a-b: Specimen with rectilinear chambers inside a bored coral exhibiting a final fistulose chamber with branched terminal projections (from Wernli and Fookes, 1992, Pl. 2, Fig. 5). Note that the test apex does not reach the base of the boring marked by a white dotted line in $b$. Scale bar $1 \mathrm{~mm}$. c: Two specimens boring into a pelecypod shell. The black rectangle marks the detail shown in $d$. Scale bar $1 \mathrm{~mm}$. d: Detail from c (from Wernli and Fookes, 1992, Pl. 1, Fig. 15) showing the voluminous last fistulose chamber (yellow transparent). Scale bar $0.3 \mathrm{~mm}$. e: Specimen with six uniserially arranged chambers of which the broad final chamber displays fistulose extensions, visible on the left side (modified from Wernli and Fookes, 1992, Pl. 1, Fig. 13). Scale bar $0.2 \mathrm{~mm}$. f: Specimen boring into a pelecypod shell. Note the rather long cavity displaying change of direction at the lower part (modified from Wernli and Fookes, 1992, Pl. 1, Fig. 11). Scale bar $1 \mathrm{~mm}$.

Two different parts can be distinguished: an early part with uniserially arranged chambers that may be followed by a part with variously branched chambers (e.g., Fig. 5a). Of course, the latter part may be missing in juvenile specimens. Specimens boring in Studia UBB Geologia, 2012, 57 (2), 17 - 26 
skeletal substrates, always display rectilinear or slightly bended tests of some uniserially arranged chambers (e.g., Figs. 4a, b). According to Schmid and Leinfelder (1996), this stage consists of maximum seven or eight chambers. As this feature was discussed by Schmid and Leinfelder (1996) with respect to the way of life (see separate chapter below), it is stressed here that this stage may be composed of much more chambers, e.g., thirteen in the specimen illustrated in Fig. 5a. Already Wernli and Fookes (1992,

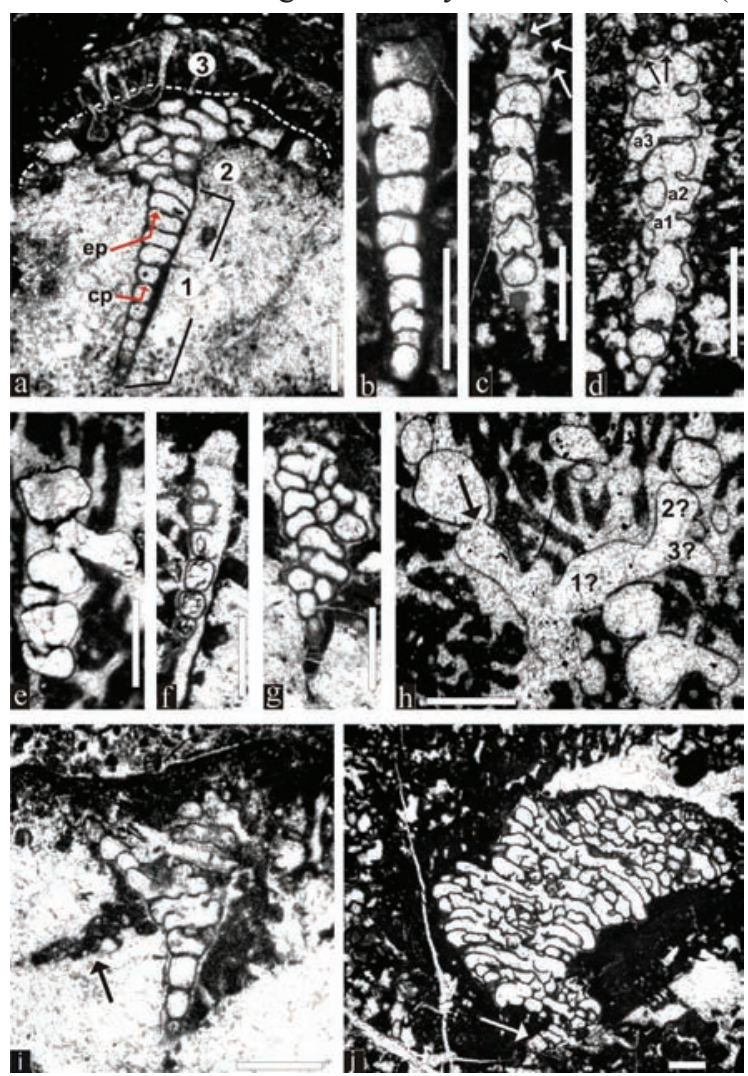

Fig. 5. Troglotella incrustans WERNLI \& FOOKES from the Upper Jurassic of the Northern Calcareous Alps of Austria (a-i), and the Eastern Carpathians of Romania (j). a: Specimen showing two stages: uniserial (1), and irregular branching (2) with radiating terminal chamberlets (3). Note the change of the chamber foramina position from central in the first chambers of the uniserial stage (cp) to excentric (ep). Mount Dietrichshorn, sample Die 170-a. b: Specimen with 10 uniserial chambers. Mount Barmsteine, sample B 133. c: Specimen boring into calcimicrobial crust showing two stages: uniserial and fine terminal chamberlets. Locality Knallalm, thin-section MR 112. $\boldsymbol{d}$ : Specimen boring into a calcimicrobial crust and exhibiting irregular chamber shapes, e.g., a1-a3. Mount Rötelstein, thin-section PS 48. $\boldsymbol{e}$ : Specimen showing irregular chamber with pronounced lateral growth, Mount Dietrichshorn, thin-section Die 170g. f: High-conical uniserial specimen boring into a stromatoporoid skeleton and with the top part into the overlying calcimicrobial crust. Note the incomplete infilling of the boring. Mount Dietrichshorn, thin-section Die 170a. g: Specimen with a short uniserial stage boring into a coral and an irregular part with agglomerated chambers. Mount Zwerchwand, thin-section $B$ 69. $\boldsymbol{h}$ : Specimen boring into an oncoid exhibiting wide angle branching. Chambers are usually separated by distinct constrictions (arrow), in some cases, however, these lack making the differentiation of individual (or branching) chambers difficult (1?-3?). Mount Dietrichshorn, thin-section Die 170g. $\boldsymbol{i}$ : Specimen exhibiting an initial uniserial stage, followed by both an irregular stage (on the right) and an uniserial stage (on the left) leaning against the hard substrate. Note the empty boring of unknown producer on the left (arrow) most likely produced by Troglotella incrustans. Mount Trisselwand, thin-section MT 105.j: Specimen boring into a calcimicrobial crust exhibiting a short uniserial stage (arrow) followed by a continuously widening and bending irregular stage with several extremely broad chambers (from Bucur and Săsăran, 2011, Pl. 4, Fig. 12). Scale bars =0.5 mm, except e $=0.3 \mathrm{~mm}$.

Studia UBB Geologia, 2012, 57 (2), 17 - 26 p. 98) mention up to 14 uniserially arranged chambers in rather long specimens they considered to belong to the microspheric generation. The chambers of the rectilinear stage are connected by means of short neck-like extensions or tubes (diameter 0.01-0.03 mm) (e.g., Figs. 4a, 5c). During growth, the chamber shape and width of the rectilinear stage may change. The first chamber is always circular; subsequent chambers gradually become more and more rectangular. Circular shapes are also observable in shallow longitudinal-tangential sections of adjacent chambers that appear separated from each other (Fig. 3b). In some cases the width of the chambers only slightly increases (Figs. 5b, d), whereas in others the shape (in longitudinal sections) becomes rectangular compressed (width/height ratio $\sim 3$ ) (Fig. 5a, last chamber of the rectilinear stage). Most chambers are more or less symmetrical to the longitudinal axis (Figs. 5a, b, d) but some may exhibit irregular shapes meaning completely asymmetrically, e.g., with one side of pronounced lateral growth (Fig. 5e). Sometimes it is difficult to decide whether irregular chambers are individual chambers or only some kind of appendages. Tests boring into (hard) skeletal substrates do not show such irregular chambers that only were observed in microbial crusts that obviously still possessed some kind of flexibility during penetration by the foraminifer. It is worth to mention, however, that tests boring into microbial crusts do not all necessarily display irregular chamber growth (Fig. 5b). In the specimen shown in Fig. 5i, the irregular final part develops within the calcimicrobial crust enveloping the bored bioclast whereas within the same test part, uniserially arranged chambers grow along the hard substrate that functioned like a support. Occasionally, both stages within the same lower part of the test can be observed also in specimens in calcimicrobial crusts (Fig. 6c).
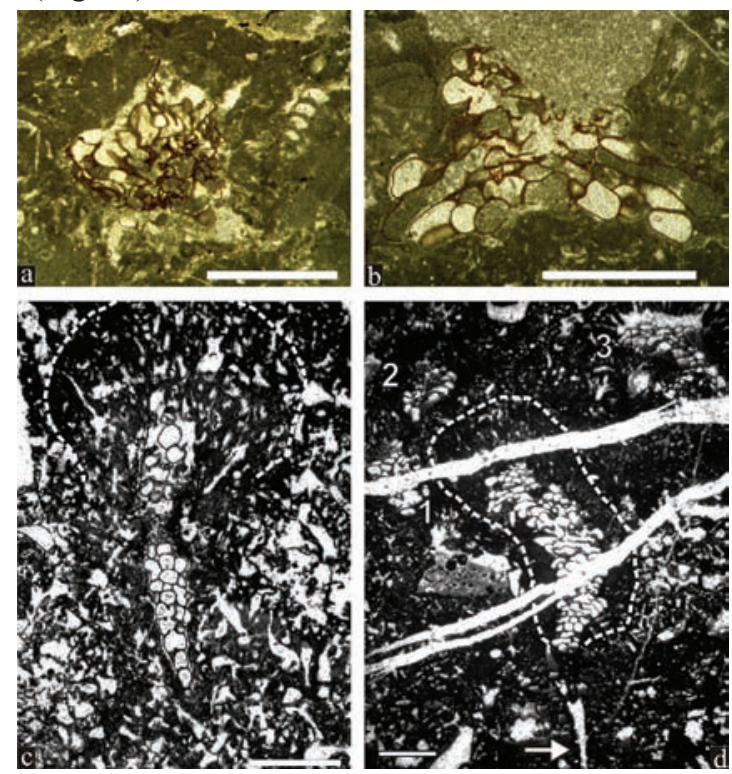

Fig. 6. Troglotella incrustans WERNLI \& FOOKES from the Upper Jurassic of the Northern Calcareous Alps of Austria (a-b) and the Eastern Carpathians of Romania $(\boldsymbol{c}-\boldsymbol{d})$. $\boldsymbol{a}$-b: Irregular adult test part within calcimicrobial crust. Note impregnation of chamber walls with iron oxides. Barmstein Limestone, Salzburg Calcareous Alps, thin-section L 433-4. c: Specimen boring into a calcimicrobial crust exhibiting an uniserial stage followed by a part of branching closely agglomerated chambers forming a cone (from Săsăran, 2006, Fig. 4.24-1). The final radiating stage is marked by the white dotted line. d: Same as for c. Note the cone-shaped uniserial initial stage within a partly empty boring (arrow) and the s-shaped form of the whole test. Numbers 1-3 denote other specimens of Troglotella incrustans. Scale bars $=1 \mathrm{~mm}$. 
The irregular-branching part normally develops immediately when the test reaches the substrate surface spreading laterally in microbial crusts that were covering the bioclasts (Figs. 5a, j). The morphology of such specimens were compared with an umbrella or champignon by Wernli and Fookes (1992, p. 97) (e.g., Fig. 5a). In rare cases we also find adult specimens of some millimeters length (up to 4 $\mathrm{mm}$ ) composed only of uniserial chambers (up to about 22) (Fig. 7b). The irregular adult stage may be composed of either a close-set agglomeration of subglobular chambers without interspaces (e.g., Figs. 5d, k, 6c-d) or an arborescent-like growth resulting from wide-angle branching of the chambers (Fig. 5h). The shape of close-set chambers may become highly variable so that the whole structure resembles to some extent "bacinellid" fabrics (Fig. 6a). Branching may occur by the formation of laterally offset new chambers connected by short and thin necks. In this case, the two chambers that form the branching are clearly recognizable and distinguishable. Often, however, branching at the end of the chamber results without distinct constrictions and short necks between them (Fig. 5h).

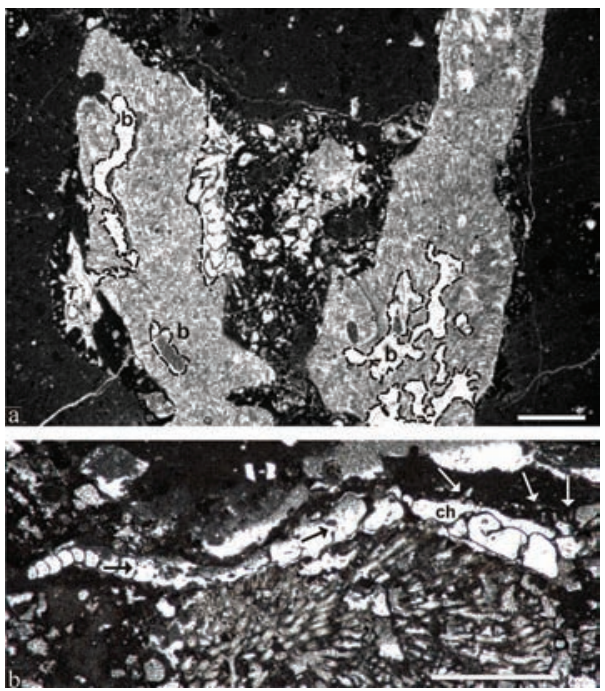

Fig. 7. Troglotella incrustans WERNLI \& FOOKES from the Upper Jurassic of the Crimea Mountains, S-Ukraine (material M. Krajewski). a: Stromatoporoids exhibiting partial calcimicrobial encrustations and specimens of Troglotella incrustans (T) boring into the latter and the skeleton. Note the empty meandering boring galleries (b) with varying diameter of an unknown producer. This boring resembles Meandropolydora osmameliensis (see Görmüs and Nielsen, 2006) (picture from Krajewski, 2010: Table 4.67.A; thin-section KD 12a). b: Large test with more than 24 rectilinear chambers lacking an irregular final part. The specimen with a total test length of $\sim 4.5 \mathrm{~mm}$ (bended!) is interpreted as boring into a calcimicrobial crust that overgrows a rivulariacean-type alga. White arrow shows the extensions/chamberlets arising from a huge final chamber (ch; not a cavity!). Black arrows indicate neck-like chamber connections. Thin-section KE 4c. Scale bars $1 \mathrm{~mm}$.

Here the delimitation of individual chambers is difficult. Both branching types can be observed within the same specimen. Nice specimens of Troglotella incrustans exhibiting a well developed and prominent irregular adult stage were figured by Bucur and Săsăran (2011, Pl. 4, Fig. 4, Pl. 5, Figs. 4-6) from the Upper Jurassic of the Eastern Carpathians, Romania boring into calcimicrobial ("bacinellid" and "porostromate") crusts. The specimen illustrated in Fig. 5j (from Bucur and Săsăran, 2011, Pl. 5, Fig. 6) shows a short rectilinear juvenile stage that broadens rapidly with irregular chambers some of which with an extreme width/height ratio $(>10)$. Two more examples of comparable test morphology are shown in Figs. 6c (from Săsăran, 2006, Fig. 4.24-1) and 6d (from Bucur and Săsăran, 2011, Pl. 4, Fig. 12). Within the "bacinellid" crust, some kind of microstructurally different aurae around the foraminifean tests are discernible. It is assumed that it delineates the zone that is influenced by the pseudopodial etching processes (see below). Wernli and Fookes (1992), Schmid (1996) and Schmid and Leinfelder (1996), however, generally describe the adult stage as encrusting. Instead, the examples mentioned before, suggest that also the irregular adult stage had the capability to bore/etch.

An observation so far not mentioned by previous workers, is the presence of a huge and broad terminal chamber with radiating extensions or chamberlets (fistulose type). This fistulose chamber may directly follow the uniserial (Figs. 4ab, d-e, 8a-b) or the irregular-branching stage (Fig. 8d). The fistulose end-chamber, however, is only developed in full grown adult specimens (e.g., Fig. 4b) and is lacking in juvenile speciens that died before reaching full test size (e.g., Fig. 4f).
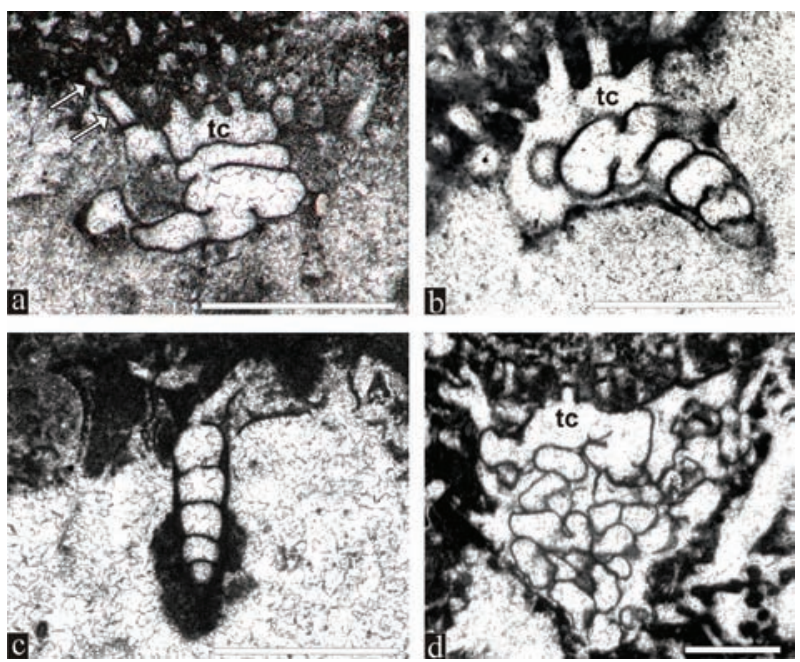

Fig. 8. Troglotella incrustans WERNLI \& FOOKES from the Upper Jurassic of the Crimea Mountains, S-Ukraine (material M. Krajewski) (a, c), Madonie Mountains of Sicily, Italy (material I. Bucur) (b) and the Northern Calcareous Alps of Austria (d). a: Bended specimen in bioclastic substrate exhibiting irregular final stage with broadening chambers and fistulose terminal chamber (tc), partly with protrusion of thin cylindrical chambers (arrow). Thin-section KB 51-L. b: Specimen comparable to a. Thin-section J 109 (from Bucur et al., 1996, Pl. 5, Fig. 10). c: Specimen with five uniserial chambers and barely visible irregular adult part (on the right). Note the bottleshaped boring that differs from the cylindro-conical foraminiferan test most likely indicating the occupation of a boring produced by another organism. Thin-section KB 39. d: Specimen with adult test portion showing agglomerated chambers. Note the broad final chamber from the roof of which several fistulose terminal chambers (tc) arise. Mount Trisselwand, thin-section MT 802. Scale bars $0.5 \mathrm{~mm}$.

Whereas the chamber foramina (= the connection between successive chambers, see Hottinger, 2006, for terminology) are single (central or excentric in position), the aperture (= the primary opening of the foraminiferal shell cavity towards the ambient environment, op. cit.) of the fistulose end-chamber is multiple. Directly arising from the endings of these final test extensions, fine-branching sparitic canals can be observed radiating into the microbial crusts and ending shortly before the crust surfaces. In the detailed view shown in Fig. 9b, it is evident that these fine canals are lacking between individual terminal chamberlets. They are interpreted as the etching traces of the filamental, branching pseudopods of the foraminifera. With diameters of 0.01 to $0.1 \mathrm{~mm}$, they most likely do not reflect Studia UBB Geologia, 2012, 57 (2), 17 - 26 
the diameter of the pseudopodia but presumably additionally include a dissolved area around each filament. This conclusion leads to a tricky situation in the cases where the calcimicrobial crusts are bored by both sponges and Troglotella incrustans and when the latter furthermore occurs as cryptoendolith in the former (e.g., Fig. 1). The size of both the sponge chambers and the radiating canals are distinctly larger as the boring galleries of Troglotella (e.g., see the size discrepancy of both in Fig. 1). Remember that with the assumed adult encrusting stage of Troglotella incrustans by Schmid and Leinfelder (1996) all sparite-filled structures ("chambers", "alveoles") were ascribed to Lithocodium aggregatum ELLIOTT.

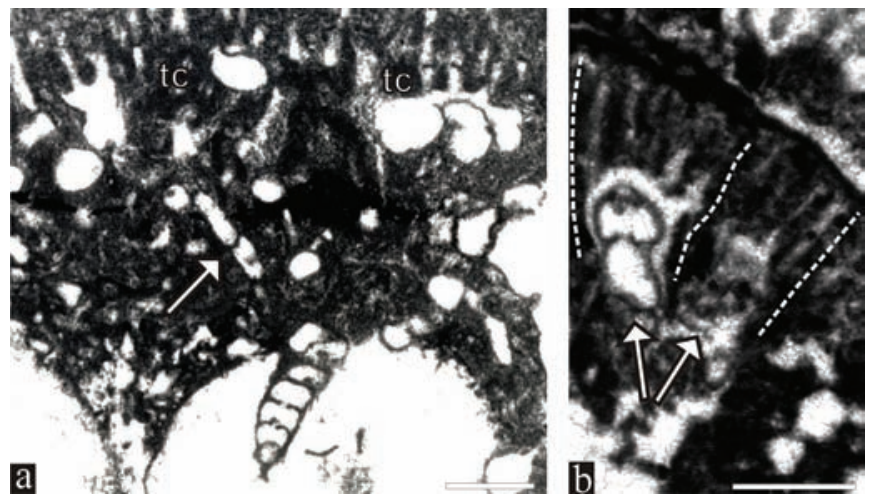

Fig. 9. Troglotella incrustans WERNLI \& FOOKES from the Upper Jurassic of the Madonie Mountains of Sicily, Italy (material I.I. Bucur) (a) and the Northern Calcareous Alps of Austria (b). a: Specimen boring into a coral with its initial uniserial part, afterwards radiating into the thick calcimicrobial crusts. Tc = terminal chamberlets. b: Specimen boring into an oncoid with branching etching traces radiating from the distal ends of the ultimate branching chambers. Mount Plassen, thin-section Pl 98. Scale bars $0.25 \mathrm{~mm}$.

Several foraminifera, e.g., representatives of the Polymorphinidae, are known to have irregular end-chambers (Barnard, 1949, 1962; Pozaryska and Voigt, 1985). The fistulose final chambers in Troglotella are aberrant with respect to the other chambers, but not abnormal as they are the normal case observable in many specimens. A nice example of a foraminifer with fistulose final chamber is Globigerinoides fistulosus (Schubert) (Fig. 10), an important Late Neogene marker taxon (e.g., Krasheninnikov, 1974; Berggren et al., 1985; Chaisson and D'Hondt, 2000; Sinha and Singh, 2008). In G. fistulosus, the extensions of the final enlarged chamber are usually arranged in line like fingers on a hand (e.g., Bolli and Saunders, 1985).

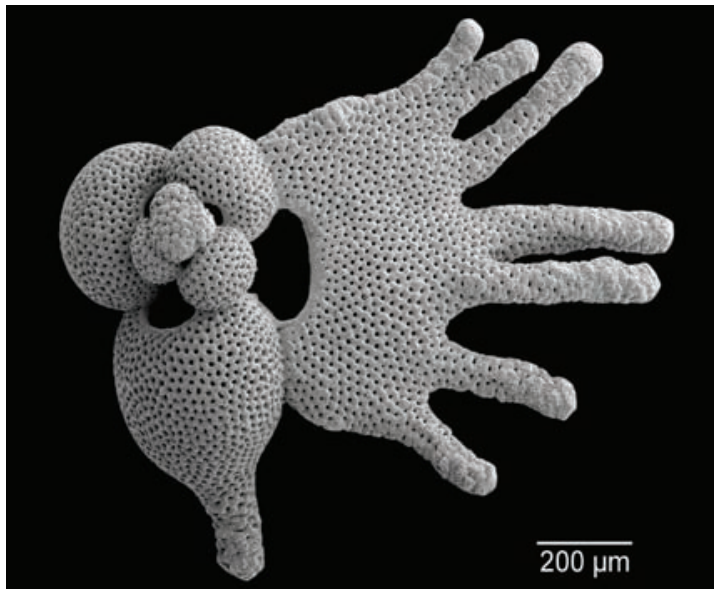

Fig. 10. Late Neogene planktonic foraminifer Globigerinoides fistulosus (Schubert) with fistulose final chamber, South Pacific Ocean. (C) copyright Bundesanstalt für Geowissenschaften und Rohstoffe (BGR), Hannover, 2005.

Studia UBB Geologia, 2012, 57 (2), 17 - 26
As in the case of Troglotella we are dealing with random thinsections and not isolated specimen, it is unknown whether there is an equivalent or irregular arrangement that covers the whole surface of the final chamber. It must be stressed here, that a direct comparison between planctonic and benthic foraminifera that exhibit completely different test microstructure, way of life and test functional-morphology is not intended. Instead, the example of the planctonic foraminifer has been selected only to show the morphology of fistulose final chamber that in Troglotella incrustans maybe obscured.

Way of life: Wernli and Fookes (1992) described Troglotella incrustans as a calcicavicole foraminifer (or secondary nestler), meaning "an organism inhabiting a space excavated by another organism or by nonbiogenic forces in a hard calcareous substratum" (Carriker and Smith, 1969, p. 1012). Wernli and Fookes (1992) were discussing a possible boring way of life of Troglotella but refuted this idea for several reasons. For benthic foraminifera it is generally suggested that the boring (or etching) process by means of their pseudopodia is chemical in nature as it cannot be the result from the activity of differentiated organs, e.g., such as rasps, known from other bioeroding organisms (e.g., Alexander and DeLaca, 1987; Vénèc-Peyré, 1987, 1996). As reasons for bioerosion in benthic foraminifera, protection in high-energetic depositional settings, feeding of organic matter in the substrate or the allocation of test-building material is assumed (e.g., Vénèc-Peyré, 1996). Wernli and Fookes (1992) recognized an obvious constructional incompatibility with a conical test whose smallest part (= apex) is at the base of the cavity and pseudopodia that (due to the imperforate wall structure of Troglotella) only could protrude from the aperture at the opposite terminal end. In fact, the close fitting of the test inside the cavity was interpreted as an indication for the adaption to an existing cavity. In that way, the fragile tests with their thin neck-like chamber connections were fixed on all sides as a perfect conservation against breakage.

In contrast hereto, Schmid (1996) considers Troglotella to be a bioeroding taxon and represented a model to explain the problems that Wernli and Fookes (1992) had posed (Fig. 11).

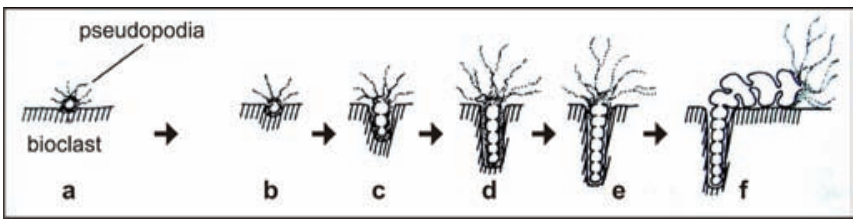

Fig. 11. Way of life of Troglotella incrustans according to Schmid (1996, Fig. 90, modified, without scale). a-e: juvenile boring stage and $\mathrm{f}$ : encrusting adult stage.

Accordingly, the substrate should be bored downward starting with the embryonic chamber while new chambers are added time-equivalent upwards. Etching should be enabled by means of the pseudopodia that reach the apex in the small space between test and substrate. For this reason, the test size of the juvenile part should limit the boring depth. For Schmid and Leinfelder (1996), the critical size should be not more than eight chambers. If this critical size is reached, downward boring should stop and instead the irregular, supposedly encrusting stage should develop. With respect to this assumption, Schmid (1996, p. 176) refers to Haynes (1981) stating that the pseudopodia might reach a length of three times the test diameter. In the models of Wernli and Fookes (1992) and Schmid (1996, adopted by Schmid and Leinfelder 1996), the greatest width of the cavity or boring should be at the substrate surface as the test 
of Troglotella widens during growth. Findings of rather long tests closely "sticking" in bioclasts (Fig. 5a), or specimens inside club-shaped cavities exhibiting smaller diameter at the substrate surface (Fig. 12), however necessitate a modified interpretation. In the specimen shown in Fig. 5a, the juvenile stage "sticking" in the substrate is composed of about 13 uniserial chambers. This test part has a length of $\sim 1.5 \mathrm{~mm}$ and a greatest width referring to the last uniserial chamber of $\sim 0.35$ $\mathrm{mm}$. Coming back to the above indicated statement of Haynes (1981), the pseudopodia are not long enough to reach down from the last uniserial chambers towards the base of the cavity.
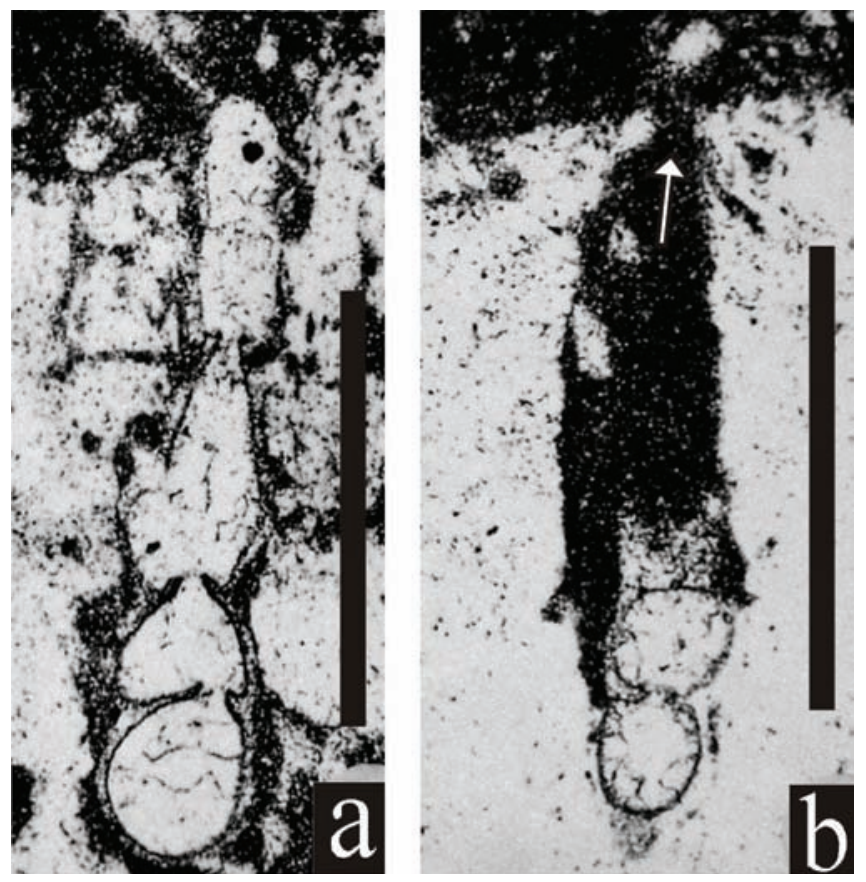

Fig. 12. Troglotella incrustans WERNLI \& FOOKES from the Upper Aptian of the Northern Calcareous Alps of Austria (from Schlagintweit, 1991: Pl. 10, Figs. 13-14 figured as "boring foraminifer gen. et $s p$. indet.). Note the small diameter of the boring entrance with respect to the maximum observed width of the test. Scale bars $0.5 \mathrm{~mm}$.

Specimens located inside bottle-shaped cavities whose greatest width distinctly exceeds the maximum test diameter (Fig. 8c) can in fact be explained by the occupation of an existing boring produced by an unknown organism, corresponding to the calcicavicole model of Wernli and Fookes (1992). Another explanation would be that the juvenile specimen died before reaching the substrate surface. As already discussed before, the etching process is assumed to have happened by means of the pseudopodia extruding from the single test aperture (in juvenile specimen). The empty cavity directly above the foraminiferan test could then represent the etched space that lateron would have been filled by successive chambers added (Cherchi and Schroeder, 2004; and pers. comm.). The inconsistences of the previous models can be explained for with another one proposed by Cherchi and Schroeder (2004, pers. comm.) that unfortunately, has not yet been published. Consulting the model of Schmid (1996), the first part with an embryo attaching to a calcareous substrate (bioclast, oncoid) and then boring downwards, remains identical. In the model of Schmid (1996), however, new chambers are successively added with drilling heading (Fig. 11) whereas Cherchi and Schroeder assume that the embryo bores downward with continuous diameter until the base of the cavity (Fig. 13) or colonize existing fissures or cracks. Then in a second stage the foraminifer bored upwards while adding new chambers and thereby continuously widening the boring and thereby attaching closely towards the surrounding substrate.

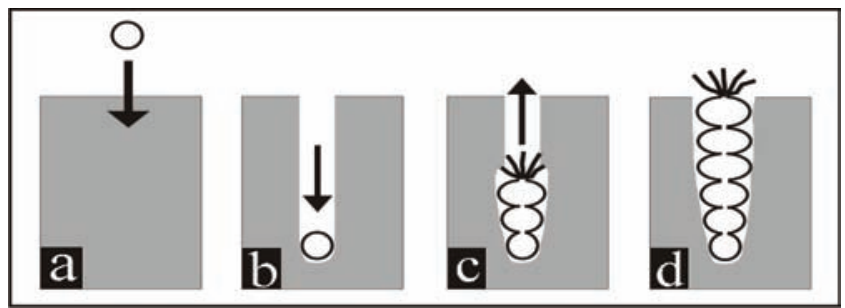

Fig. 13. Way of life of Troglotella incrustans based on a model expressed by Cherchi and Schroeder (2004). a-b: Embryo boring downward into the substrate and afterwards (c-d) growing upwards by adding new chambers attending by a successive broadening of the initial boring.

According to Cherchi and Schroeder (2000, p. 43) the embryo was boring into the bioclast along existing fissures. If so (what cannot be proven), it is considered an exceptional and incidential case as a protist unlikely had the possibility to scan the substrate surface for favored entrance points. Independently hereof, the change of the microstructure or mineralogical composition of bored skeletal bioclasts, that could influence its durability against etching, might have an influence on the shape of the boring gallery. Such a context is known for example from euendolithic chlorophyts (e.g., Golubic et al., 1975).

Among the borings containing Troglotella specimens and empty ones associated with them, different types can be distinguished:

(A) straight or slightly bended cavities of cylindro-conical shape completely filled with the tests of Troglotella (e.g., Fig. 4a, e)

(B) as (A), but empty (without tests of Troglotella) (e.g., Fig. 5i, arrow)

(C) meandriform, rather long, empty borings (e.g., Fig. 7a)

(D) rather long borings, straight or bended, with test of Troglotella only at the base (e.g., Fig. 4f).

Type A borings are interpreted as having excavated by Troglotella itself. The same accounts for the empty boring in Figure 5i (type B), which in its upper broader part shows some rounded bulges that seem to represent the outline of the individual chambers of the test. The reason for the boring being empty without the foraminiferan test stacking inside is unknown. The undulating tubiform (meandriform) borings (type C) resemble structures described from the test of Upper Cretaceous larger foraminifera (Nielsen and Görmüş, 2004; Görmüş and Nielsen, 2006). The producer of this boring is unknown. Type D boring represents a single example observed within a pelecypod shell. The boring organism, supposedly Troglotella itself, was boring parallel to the shell surface (and its microstructure) then changing direction. In this example, the test bending cannot be explained by the occupation of an existing cavity requiring a flexible calcareous test. The bending of the test inside some cavities was also taken as an argument by Wernli and Fookes (2002) as accommodation to a pre-existing cavity. On the other side, there are no arguments excluding a slight and gradual change in the direction of substrate boring of the embryo. A possible reason could be a movement/turning of the bioclastic substrate during the penetration process that would indicate heliotrophic or phototrophic controlled growth. This could perhaps be the explanation for specimens inside cavities that are arranged obliquely to the substrate surface (e.g., Figs. 4d, f, 8b). The 
not completely preserved specimen boring into a rudist shell and illustrated in Fig. 12b, displays a rather small entrance of the boring at the substrate surface whereas the maximum observed width of the test is distinctly greater excluding the assumptions of Wernli and Fookes (1992) and Schmid (1996).

In modern benthic foraminifera aberrant chambers may have different causes, e.g., the effects of marine pollution (e.g., Yanko et al., 1999) or the influence of submarine thermal springs (Meriç et al., 2003). In Troglotella incrustans, the general broadening of the test by multiple branching and the final chamber with a multitude of fistules and/or irregular cylindrical chamberlets is considered a strategy simply to enlarge the pseudopodial coverage for the uptake of nutrients. The larger the test of Troglotella got, the greater was the metabolic activity of the multiplied volume of the living protoplasma. The increased nutrient supply could be reached by enhanced feeding on the microbial crusts enabled by test branching and multiplication of apertural openings. This might be the reason that specimen boring into bioclasts that were not heavily encrusted by microbialites did not (or only to a reduced amount) developed the irregular final stage. Generally spoken, foraminifera "of size classes $>1 \mathrm{~mm}$, in most cases, have shapes responding to the needs of interacting with the ambient environment" (Hottinger, 2000, p. 61). Especially in Late Jurassic shallow-water lagoonal oncoid facies, specimens of Troglotella occur in high numbers indicating ideal living conditions accompanied with high reproduction rates. In any case, Troglotella incrustans is not a marker of reefal facies (with corals) as assumed by Wernli and Fookes (1992) but occurs in facies with hard substrates and/or microbial mats. In terms of general platform terminology, it occurs in both internal and external facies.
Emended diagnosis: In the original description of Wernli and Fookes (1992), no genus diagnosis was provided but a detailed description. A diagnosis was later presented by Schmid and Leinfelder (1996) modified by Schlagintweit et al. (2005) with the occurrence of branching chambers in the adult part. Due to the extremely high variability, the restriction/indication of numeric data (e.g., dimensions or number of chambers) as done by Schmid and Leinfelder (1996), in a genus diagnosis is misleading and is avoided here. Usually, diagnoses of foraminiferal genera "are generally focused on test morphology, both external and internal" (Loeblich and Tappan, 1988, p. vii), whereas numeric data are usually kept open, leaving space for species differentiation. In the case of Troglotella, however, all characteristics that can be of specific importance exhibit such a high variability (with transitions) that at present it almost appears impossible how another species could be diagnosed clearly. The emended diagnosis of Troglotella (that is identical to the diagnosis of Troglotella incrustans) is given as follows (see also Fig. 14):

"Test may consist of two morphologically different stages. Early stage uniserial cylindro-conical (straight or bended) may be situated in a cavity bored by the foraminifer itself. Chambers are spherical, cylindrical with or without asymmetric lateral outgrowths. Intracameral foramina single, normally centric but may shift to a slightly eccentric position during growth. The optional final stage is irregular with chambers variously branching either closely agglomerated or diverging in a tree-like manner. End-chamber broad, huge and fistulose with multiple apertures. Radiating and tapering extensions formed by several thin uniserial cylindrical chambers may arise from the fistulose end-chamber."

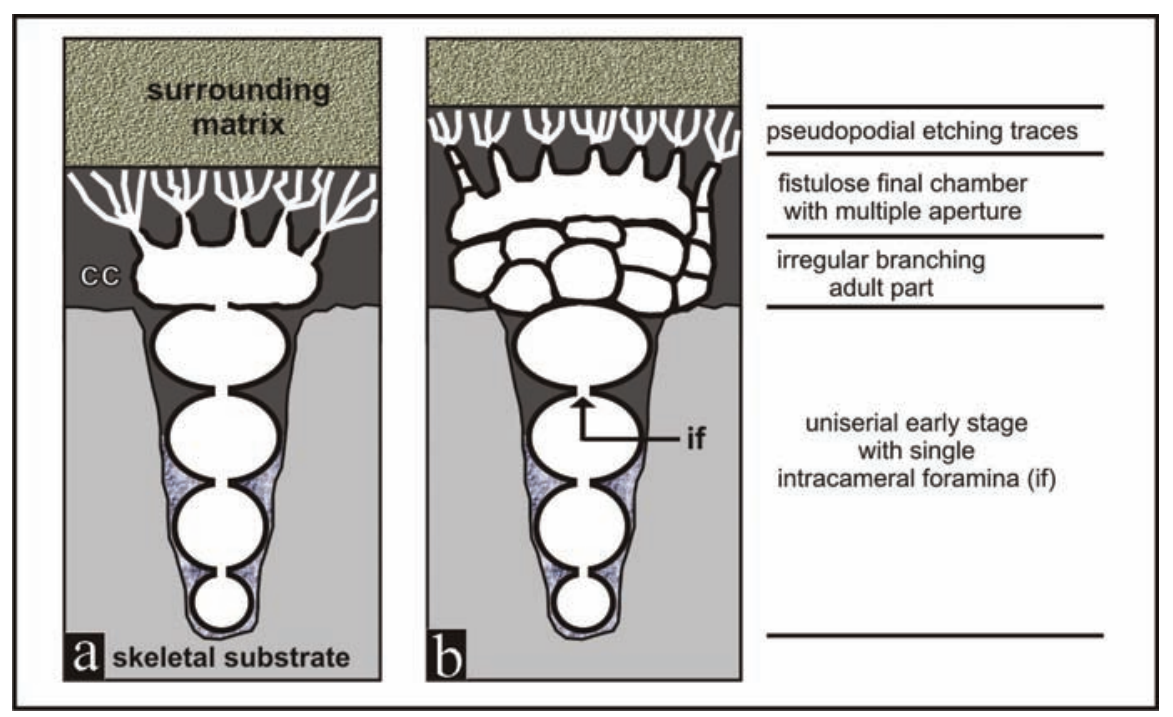

Fig. 14. Terminology and growth stages of Troglotella incrustans.

It is worth mentioning that the fine-branching canals arising from the distal ends of the fistulose outgrowths are not included in the diagnosis as they are interpreted as empty boring/etching galleries produced by the pseudopodial network.

Stratigraphy: Troglotella incrustans was described by Wernli and Fookes (1992) from the Kimmeridgian of France. Schmid and Leinfelder (1996) summarized its stratigraphic range as Middle Oxfordian to Tithonian obviously having escaped notice of the specimens figured by Schlagintweit (1991) from the Upper Aptian as boring foraminifer gen. et sp. indet. (see Fig. 12). In reviewing the literature data Kolodziej (1997) stated that the stratigraphic range of Studia UBB Geologia, 2012, 57 (2), 17 - 26
Troglotella incrustans should be extended to the Albian. Cherchi and Schroeder (2000) figured Troglotella n. sp. from the Lower Cenomanian of France that is considered to belong to the type-species as globular chambers and the partly englobing of two successive chambers, said to be speciesindicative, are also observable in morphologically highly variable Late Jurassic material. Therefore, the genus Troglotella is still considered a monospecific taxon. This Lower Cenomanian finding is the youngest record of Troglotella incrustans. Somehow older specimens were observed in the Late Albian of Hungary (Császár, 1985; Schlagintweit, 1990) (Fig. 15). 

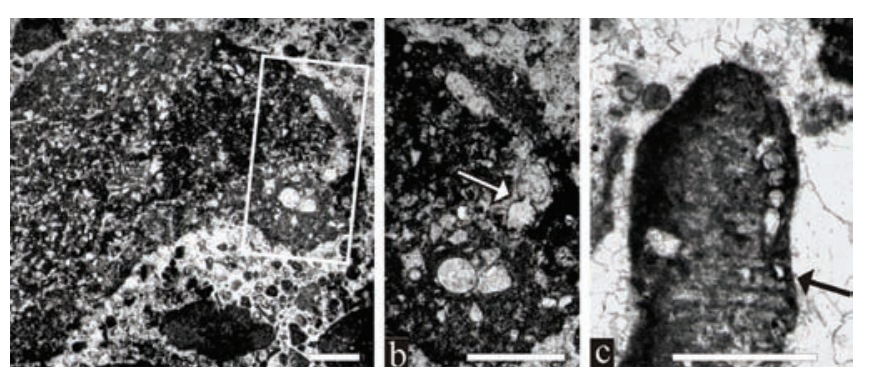

Fig. 15. Troglotella incrustans WERNLI \& FOOKES from Late Albian high-energetic deposits (orbitolinid biosparites) of Hungary a: Specimen boring into an orbitolinid test (white rectangle shows the detailed view of $b$ ). $\boldsymbol{b}$ : Detail from $a$. Note the short cylindrical connection between two successive chambers (arrow). c: Specimen boring into a bioclast parallel to its surface. The arrow shows the assumed entrance. Sample Z-1. Scale bars $0.5 \mathrm{~mm}$.

Summarizing, the stratigraphic range of Troglotella incrustans is Middle Oxfordian to Lower Cenomanian.

Acknowledgements. Photographs of the studied material were kindly provided by Ioan I. Bucur and Emanoil Săsăran (Babes-Bolyai University, Cluj-Napoca) (Upper Jurassic of Romania), Baba Senowbari-Daryan (University of Erlangen) (Upper Triassic of Austria). Parts of the Upper Jurassic material from the Northern Calcareous Alps were provided by Matthias Auer (Karlsruhe), Hans-Jürgen Gawlick, Oliver Krische and Gerd Winterleitner(University of Leoben). Jochen Erbacher and Gabriele Grützner (Bundesanstalt für Geowissenschaften und Rohstoffe, Hannover) are thanked for providing one photograph and the permission for illustration. Helpful comments provided by reviewers Antonietta Cherchi and Boguslaw Kolodziej (Kraków) are kindly acknowledged.

\section{R E F E R E N C E S}

Alexander, S.P., DeLaca, T.E. 1987, Feeding adaptations of the foraminiferan Cibicides refulgens living epizoically and parasitically on the Antarctic scallop Adamussium colbecki. The Biological Bulletin, 173 (1): 136-159.

Barnard, T. 1949, An abnormal chalk foraminifer. Proceedings of the Geological Association, 60 (4): 284-287.

Barnard, T. 1962, Polymorphinidae from the Upper Cretaceous of England. Palaeontology, 5 (4): 712-736.

Berggren, W.A., Kent, D.V. \& Van Couvering, J. 1985, The Neogene: Part 2: Neogene geochronology and chronostratigraphy. In The Chronology of the Geological Record (Snelling, N.J., Ed.), Geological Society, London, Memoirs 10: 211-260.

Bolli, H.M., Saunders, J.B. 1985, Oligocene to Holocene low latitude planktic foraminifera. In Plankton stratigraphy (Bolli, H.M., Saunders, J. \& Perch-Nielsen, K., Eds.), Volume 1, Cambridge Earth Sciences Series, p. 155-262.

Bromley, R.G., Kedzięrski, M., Kolodziej, B. \& Uchman, A. 2009, Large chambered borings on a Late Cretaceous abrasion platform at Cracow, Poland. Cretaceous Research, 30 (1): 149-160.

Bronn, H.G. 1838, Lethaea Geognostica. Schweizerbart, Stuttgart (Atlas 1837, text 1838).

Bucur, I.I., Săsăran, E. 2011, Upper Jurassic-Lower Cretaceous algae of Hăghimaş Mountains (Lacu Roşu-Cheile Bicazului area). In Calcareous algae from Romanian Carpathians (Bucur, I.I., Săsăran, E., Eds.). Field Trip Guidebook. $10^{\text {th }}$ International Symposium on Fossil
Algae Cluj-Napoca, 12-18 September 2011, p. 57-96.

Bucur, I.I., Senowbari-Daryan, B. \& Abate, B. 1996, Remarks on some foraminifera from the Upper Jurassic (Tithonian) reef limestone of Madonie Mountains (Sicily). Bolletino della Società Paleontologica Italiana, 35 (1): 65-80.

Carriker, M.R., Smith, E.H. 1969, Comparative calcibiocavitology: summary and conclusions. American Zoologist, 9 (3): 1011-1020.

Chaisson, W.P., D'Hondt, S.L. 2000, Neogene planktonic foraminifer biostratigraphy at site 999, Western Caribbean Sea. In Proceedings of the ODP Scientific Results (Leckie, R.M., Sigurdsson, H., Acton, G.D. \& Draper, G., Eds.), 165: 19-56.

Cherchi, A., García, A., Schroeder, R. \& Segura, M. 1995, Foraminíferos cryiptobióticos en el Albiense superiorCenomaniense inferior de la Cordillera Ibérica. Reflexiones sobre unas estructuras problemáticas en Lithocodium. Revista Española de Paleontología, 10 (2): 294-293.

Cherchi, A., Schroeder, R. 2000, Foraminiferi criptobionti del Cenomaniano inferiore della Montagna di Tauch (Corbières, Francia meridionale). Giornale di Geologia, 62: 41-46.

Cherchi, A., Schroeder, R. 2004, Riflessioni sul modo di vita di Troglotella incrustans Wernli \& Fookes, foraminifero criptobionte del Kimmeridgiano. Giornate di Paleontologia 2004, Bolzano, 21-23 Maggio, (Società Italiana di Paleontologia). Riassunti, p. 20.

Cherchi, A., Schroeder, R. 2006, Remarks on the systematic position of Lithocodium ELLIOTT, a problematic microorganism from the Mesozoic carbonate platforms of the Tethyan realm. Facies, 52 (3): 435-440.

Cherchi, A., Schroeder, R. 2010, Boring sponges (Entobia) in Mesozoic Lithocodium calcimicrobial crusts. Rivista Italiana di Paleontologia e Stratigrafia, 116 (3): 351-356.

Császár, G. 1985, Middle Cretaceous formations of the Transdanubian Central Range: Stratigraphy and connection with bauxite genesis. Geologica Hungarica, Series Geologica, 23: 149-207.

Elliott, G.F. 1956, Further records of fossil calcareous algae from the Middle East. Micropaleontology, 2: 327-334.

Gawlick, H.-J., Missoni, S., Schlagintweit, F., Suzuki, H., Frisch, W., Krystyn, L. \& Lein, R. 2009, Jurassic tectonostratigraphy of the Austroalpine Domain. Journal of Alpine Geology, 50: 1-152.

Golubic, S., Perkins, R.D. \& Lukas, K.J. 1975, Boring microorganisms and microborings in carbonate substrates. In The study of trace fossils (Frey, R.W., Ed.). Springer, Berlin, p. 229-259.

Görmüş, M., Nielsen, J.K. 2006, Borings in larger benthic foraminifers from Turkey and their paleoenvironmental significance. Journal of Foraminiferal Research, 36 (2): 152-165.

Haynes, J.R. 1981, Foraminifera. London, Macmillan, 433 p.

Hottinger, L. 2000, Functional morphology of benthic foraminiferal shells, envelopes of cells beyond measure. Micropaleontology, 46 (suppl. 1): 57-86.

Hottinger, L. 2006, Illustrated glossary of terms used in foraminiferal research. Carnets de Géologie. Notebooks on Geology Memoire 2006/02 (CG2006_M02).

Kolodziej, B. 1997, Boring foraminifera from exotics of the Stramberk-type limestones (Tithonian-Lower Berriasian, Polish Carpathians). Annales Societatis Geologorum Poloniae, 67: 249-256.

Studia UBB Geologia, 2012, 57 (2), 17 - 26 
Krajewski, M. 2010, Facies, microfacies and development of the Upper Jurassic-Lower Cretaceous of the Crimean carbonate platform from the Yalta and Ay-Petri massifs (Crimea mountains, southern Ukraine). Dissertation Monographs (Wydawnictwa AGH, Kraków), 217: 1-253.

Krasheninnikov, V.A. 1974, Planktonic foraminiferal biostratigraphy of Pliocene and Quarternary deposits of the East Pacific Rise and the Galapagos spreading center Deep Sea Drilling Project Leg 54. Deep Sea Drilling Project Reports and Publications, 27: 509-533.

Loeblich, A.R., Jr., Tappan, H. 1988, Foraminiferal genera and their classification (two volumes), Van Nostrand Reinhold, New York, 970 p.

Meriç, E., Avşar, N., Bergin, F. \& Barut, I.F. 2003. A note on three abnormal samples of benthic foraminifers from the Dikili Bay (Turkey) in the northeastern Aegean Sea: Peneroplis planatus (Fichtel and Moll), Rosalina sp., and Elphidium crispum (Linné). Mineral Research Exploration Institute Bulletin, 127: 1-14.

Nielsen, J.K., Görmüş, M. 2004, Ichnotaxonomy and ethology of borings in shallow-marine benthic foraminifers from the Maastrichtian and Eocene of northwestern and southwestern Turkey. Rivista Italiana di Paleontologia e Stratigrafia, 110 (2): 493-501.

Pozaryska, K., Voigt, E. 1985, Bryozoans as substratum of fossil fistulose Foraminifera (Fam. Polymorphinidae). Lethaia, 18: 155-165.

Santos, A., Mayoral, E. \& Bromley, R.G. 2011, Bioerosive structures from Miocene mobile-substrate communities in southern Spain, and description of a new sponge boring. Palaeontology, 54 (3): 535-545.

Săsăran, E. 2006, Calcarele Jurasicului Superior-Cretacicului Inferior din Munții Trascău. Cluj University Press, Cluj-Napoca, 249 p.

Schlagintweit, F. 1990, Microfaunistic investigations of Hungarian Urgonian limestones (Barremian-Albian). Acta Geologica Hungarica, 33 (1-4): 3-12.

Schlagintweit, F. 1991, Allochthone Urgonkalke im Mittleren Abschnitt der Nördlichen Kalkalpen: Fazies, Paläontologie und Paläogeographie. Münchner geowissenschaftliche Abhandlungen, 20: 1-120.

Schlagintweit, F. 2010, Taxonomic revision of Lithocodium aggregatum ELLIOTT sensu Schmid \& Leinfelder, 1996. Jahrbuch der geologischen Bundesanstalt, 156 (3-4): 393-406.

Schlagintweit, F. 2011, Taxonomic revision of Late Triassic „Lithocodium aggregatum ELLIOTT“ (Northern Calcareous Alps, Austria). Jahrbuch der geologischen Bundesanstalt, $151(3-4):$ 375-396.
Schlagintweit, F., Bover-Arnal, T. \& Salas, R. 2010, New insights into Lithocodium aggregatum ELLIOTT 1956 and Bacinella irregularis RADOIČIĆ 1959 (Late JurassicLower Cretaceous): two ulvophycean green algae (?Order Ulotrichales) with a heteromorphic life cycle (epilithic/ euendolithic). Facies, 56 (4): 509-547.

Schlagintweit, F., Bover-Arnal, T. 2012, The morphological adaption of Lithocodium aggregatum ELLIOTT (calcareous green alga) to cryptic microhabitats (Lower Aptian, Spain): an example of phenotypic plasticity. Facies, 58: 37-55.

Schlagintweit, F., Gawlick, H.-J. \& Lein, R. 2005, Mikropaläontologie und Biostratigraphie der Plassen-Karbonatplattform der Typlokalität (Ober-Jura bis Unter-Kreide, Salzkammergut, Österreich). Journal of Alpine Geology (Mitt. Ges. Geol. Bergbaustud. Österreich), 47: 11-102.

Schmid, D.U. 1996, Marine Mikrobolithe und Mikroinkrustierer aus dem Oberjura. Profil, 9: 101-251.

Schmid, D.U., Leinfelder, R.R. 1996, The Jurassic Lithocodium aggregatum-Troglotella incrustans foraminiferal consortium. Palaeontology, 39 (1): 21-52.

Schönberg, C.H.L., Tapanila, L. 2006, The bioeroding sponge Aka paratypica, a modern tracemaking analogue for the Paleozoic Ichnogenus Entobia devonica. Ichnos, 13 (3): 147-157.

Sinha, D.K., Singh, A.K. 2008, Late Neogene planktic foraminiferal biochronology of the ODP site 763A, Exmouth Plateau, Southeast Indian Ocean. Journal of Foraminiferal Research, 38 (3): 251-270.

Tapanila, L. 2006, Devonian Entobia borings from Nevada, with a revision of Topsentopsis. Journal of Palaeontology, 80 (4): 760-767.

Vénèc-Peyré, M.T. 1987, Boring foraminifera in French-Polynesian coral reefs. Coral Reefs, 5: 205-212.

Vénèc-Peyré, M.T. 1996, Bioeroding foraminifera: a review. Marine Micropaleontology, 28: 19-30.

Wernli, R., Fookes, E. 1992, Troglotella incrustans n. gen., n. sp., un étrange et nouveau foraminifère calcicavicole du complexe récifal Kimméridgien de Saint-Germain-deJoux (Ain, France). Bolletino della Societa Paleontologica Italiana, 31: 95-103.

Yanko, V., Arnold, A.J. \& Parker, W.C. 1999, Effects of marine pollution on benthic foraminifera. In Modern Foraminifera (Sen Gupta, B.K., Ed.). Kluwer Academic Publishers, Amsterdam, p. 217-235. 